\title{
Exploring the Concept of Third Space within Networked Social Media
}

\author{
Chamari Edirisinghe ${ }^{1,3}$, Ryohei Nakatsu ${ }^{2}$, Adrian Cheok $^{1}$, and Johannes Widodo ${ }^{3}$ \\ ${ }^{1}$ Keo-NUS Cute Center, NUS, 21, Heng Mui Keng Terrace, Singapore 119613 \\ ${ }^{2}$ Interactive Digital Media Institute, NUS, 21, Heng Mui Keng Terrace, Singapore 119613 \\ ${ }^{3}$ Department of Architecture, School of Design \& Environment, NUS, 4 , \\ Architecture Drive, Singapore 117566 \\ \{chamariadriancheok\} @mixedrealitylab.org, \\ \{idmdir, jwidodo\} @nus. edu.sg
}

\begin{abstract}
Third Space is thinking differently of the significance and meanings of space progressing beyond the inadequacy of dualism, as in mental and physical space. The discourse on Third space emerges to set aside the 'either/or' manner of binary categorizing to encompass 'both/and also' logic that allows an 'Other' set of options. The online social networking is the newest thing in creating connectivity and the identities. This paper is an attempt to comprehend and recognize the dynamics of the concept of Third space through the online social networking realm.
\end{abstract}

Keywords: Social Space, Third Space, Social Networks, Hybridity, Difference, Radical Openness.

\section{Introduction}

Space is a fundamental area of study in many disciplines. Plato stressed that matter and space are the same and Aristotelian world is a plenum (space filled with matter). Descartes has rejected both Aristotelian and anti-Aristotelian thoughts on space, instead defined the material substance within the three dimensional spatial extension [8]. Kant's [5] notion of space is neither Aristotelian nor Cartesian, but a priori, which shifted the discourse of space from philosophy to science. Heidegger [2] was the first to introduce the notion that the existence is spatial. Norberg-Schulz [7] believed that the human interest in space appeared from the need to comprehend the environmental relations that surround him, to give meanings and order to the events and actions.

The noticeable dynamism in the spatial discussion is its dualism and privileging one over the other. According to Henri Lefebvre [6], the philosophical space is given precedence over the social and physical space. The space between the philosophical epistemologies and the physical or the social space is the space that was overlooked, disregarded and not conceptualized. The Third Space is this overlooked and disregarded space, a space that includes both the philosophical and social/physical and also the space that is 'in between'. The intention of this research is to examine the epistemologies of the 'in between' space or the 'third space' and its dynamisms as a space of radical openness and critical enquiry. This enquiry will be positioning the 
modern networked social media within the discourse of Third space and the phenomenon of being virtually connected on a social space; a platform of immense interactivity and communication of information.

\section{Objective}

The broad objective of this study is to clarify the spatiality of the networked social media and understand the spatial concept of Third space in relation to the modern communication media. At this point in this research, the primary objective is to establish the concept of Third space and its trajectories. Thus, form a foundation to study the second stage which would enquire into the materialization of social connections and their diffusion leading to the hypothetical position of the relationship between third space and networked social media.

\section{Concept of Third Space}

Exploring the conceptualization of the Third space begins with Lefebvre's [6] dialogue on space. He, with his discussions on the lived and conceived, the real and the imagined, analyses the discourse on space as a three-part dialectic between everyday practices and perceptions, representations or theories of space and the spatial imaginary of the time. Edward Soja is another prominent figure in highlighting the importance of Third space by familiarizing the terminology 'Thirdspace'. Soja's [9] 'Thirdspace' is tentative and flexible to capture the constant shifts in ideas, thoughts and events and meanings. "For me this space of radical openness is a margin- a profound edge. The focus was on both center and the margin understanding the contradiction on both spaces" says bell hooks [3]. Homi K. Bhabha's [1] Third space is a space of difference and hybridity. The significance of the hybridity is not to be able to trace the two original moments from where the Third space emerged but rather understanding the hybridity as the Third space, which enables other spaces to emerge. Gayatri Spivak's [11] Third space will define both center and the margin, but still operates as a space of radical resistance. Anthony Vidler's [12] 'The Third Typology' and Jane Jacobs's [4] City earmarked another approach to the Third space in urban environment.

Over the years, there materialized a shift in our knowledge of space as well as the spatial practices itself. The new spaces such as the spaces created over the internet, web camera telecasts, chat rooms with video/audio chatting, blogging and most recently the online social networking. Are these incomprehensible, imaginative yet so networked and interactive spaces contradicting the existing knowledge and conceptualization of Third space? These new developments would be briefly examined by trying to place the networked social media within the Third space criteria.

\section{Understanding Third Space in Networked Social Media}

Understanding Third Space leads us towards a discussion examining the spaces of new modernity, the spaces of actions, interactions, and concepts and theories. Online 
social networking (Facebook, MySpace, Twitter etc.) consisted of individuals, connected through a telecommunication network, interacting on one platform, which could be customized yet universally defining similar functions, ambiguous yet with one clear intention - connectivity; with an immense amount of information exchanged, shared, declared and stored. The tangibility is the visuality on an interface; intangibility is the connection that provides the access to interact with others. The spatiality is diverse, different and essentially rapid.

Let us examine the dynamics of Third Space and understand the paradigm changes with regards to the social networking realm. a) Third space clarifies the binaries in the discourse of space - By existing as connected to yet independent of the existing spaces, Third space explains the binaries, says. Bhabha[1]. Examining the social networking platforms, the differences are noticeable on a common platform, interacting, sharing information and uploading new knowledge both written and visual. It is the 'in between' space, where it is continually transforming in accordance with the dynamics of the cultural interactions. b) Third space is counter-hegemonic Social networks clearly projects the ideologies and supremacies related to information and its sharing, managing and storing. These platforms could act as authoritarian custodians of the social interactions of the people within/out of the realm of the network by dictating the behavior pattern within the site while simultaneously promoting the virtues of social connectivity though the market place. Facebook, a prominent social media platform, advocates that having a Facebook account as the only sustainable way of managing your friendships. d) Third space is both imaginative and real - This is a resemblance to the mirror; the reflection is on the mirror where the person is not. It is both imaginative and real concurrently, thus accommodating both, the person before the mirror looking in and the person reflected in the mirror looking out, the reflection and the real. On the social media platforms there exist the projection, the person on the mirror, the person who was a reflection yet not in attendance, and on the other side is physical self looking at the reflected self. e) Third space is a space of negotiation, contestation, and rearticulating - The networked social media through its interactive platforms created spaces of voices, which contest, negotiate and rearticulate the social issues, political suppression, censorship, injustice etc. The protests following the Iranian Election in 2009, Iranian government has prevented the reporting of atrocities happening within, however, people started using social network sites, as a way of broadcasting the happenings.

It could be understood that networked social media, though demonstrate strong indicators of being able to be positioned within the Third space discourse, it is still an ambiguous project with several problematic evolving. Both the Third space and the networked social media are conceptually and critically underdeveloped, which impede further developments such as understanding the dynamics critically.

\section{Conclusion and Future Work}

Social networking spaces has produced a space that operates with a hegemonic parameters, yet accumulates different values in a form of being a collective social force, thus emerging beyond the binary vision towards the Third space. Describing third space Soja [10] says that it is not an alternative concept but a space where issues 
were raised and discussed without privileging any party and actions. Potentially the positioning of networked social media among the conceptualizations of Third space offers for new knowledge on spatiality

The next step in this study is to examine the multiplicity in connectivity, where we would examine the users of networked social media to analyze the magnitude of connectivity. The succeeding study would be the establishment of the multiple interaction space which would be a further study of the extent of the connectivity and development of the argument. In the final phase we would decisively maintain our hypothetical position, which would be to establish that multiple interaction space as the third space.

Acknowledgments. This research is carried out under CUTE Project No. WBS R7050000-100-279 partially funded by the National Research Foundation (NRF) administered by the Media Development Authority (MDA) of Singapore.

\section{References}

1. Bhabha, H.K. In: the Cave of Making: thoughts on Third Space. In: Ikas, K., Wagner, G. (eds.) Communicating in the Third Space, pp. ix-xiv. Routledge, New York (2009)

2. Heidegger, M.: Being and Time. Blackwell Publishing Ltd., Warszawa (1962)

3. Hooks, B.: Yearning: Race, Gender, and Cultural Politics. South End Press, Boston (1990)

4. Jacobs, J.: The Death and Life of Great American Cities. In: Campbell, S., Fainstein, S.S. (eds.) Planning Theory, pp. 61-74. Blackwell Publishing, Malden (2003)

5. Kant, I.: Critique of Pure Reasoning. Translated by J.M.D. Meiklejohn. Dover Publications Inc., New York (1900) (2003)

6. Lefebvre, H.: The Production of Space (D. Nicholson-Smith, Trans.). Blackwell Publishing, Malden (1974)

7. Norberg-Schulz, C.: Existence, Space and Architecture. Praeger Publishers, Westport (1971)

8. Slowik, E.: Stanford Encyclopaedia of Philosophy (June 27, 2009), http: / / plato.stanford.edu/entries/descartes-physics /\#3 (accessed June 29, 2010)

9. Soja, E.W.: Thirdspace: Journey to Los Angles and other Real-and-Imagined Places. Blackwell Publishing, Malden (1996)

10. Soja, E.W.: Thirdspace: Towards a New Consciousness of Space and Spatiality. In: Ikas, K., Wagner, G. (eds.) Communication in the Third Space, pp. 49-61. Routledge, New York (2009)

11. Spivak, G.C.: Subaltern Studies: Deconstructing Historiography. In: Guha, R., Spivak, G.C. (eds.) Selected Subaltern Studies, pp. 3-33. Oxford University Press, New York (1988)

12. Vidler, A.: The Third Typology. In: Cuthbert, A.R. (ed.) Designing Cities: Critical Readings in Urban Design, pp. 317-322. Blackwell Publishing, Malden (2003) 